Muhamad Adystia Sunggara, Yang Meliana, Arifin Faqih Gunawan, Sri Yuliana, Penerapan dan Pemberian Bantuan Hukum Bagi Masyarakat Kurang Mampu, Halaman 138-154

\title{
PENERAPAN DAN PEMBERIAN BANTUAN HUKUM BAGI MASYARAKAT KURANG MAMPU
}

\author{
Muhamad Adystia Sunggara', Yang Meliana², Arifin Faqih Gunawan ${ }^{3}$, Sri \\ Yuliana $^{4}$ \\ ${ }^{1}$ Sekolah Tinggi Ilmu Hukum Pertiba Pangkalpinang \\ E-mail: dr.m.adystiasunggara@gmail.com \\ ${ }^{2}$ Sekolah Tinggi Ilmu Hukum Pertiba Pangkalpinang \\ E-mail: yangmeliana259@gmail.com \\ ${ }^{3}$ Sekolah Tinggi Ilmu Hukum Pertiba Pangkalpinang \\ E-mail: arifinfaqih22@gmail.com \\ ${ }^{4}$ Sekolah Tinggi Ilmu Hukum Pertiba Pangkalpinang \\ E-mail: srieyuliana2019@gmail.com
}

\begin{abstract}
The protection and recognition of human rights of every individual or citizen is an obligation for the state as a logical consequence of its establishment as a rule of law and a person has the right to be treated equally before the law, including for poor people who are in trouble with the law. This research is normative legal research or doctrinal legal research with a legal inventory approach, which collects norms that have been identified as legal norms. The conclusion of this study is that legal aid is not a guarantee in the form of access to law and justice for the poor because the application of legal aid at the practical level in the community still reaps several problems that hinder the realization of access to law and justice for the poor. First, the non-working normative legal framework. Second, the lack of legal awareness regarding legal aid. Third, access to justice which is formality. Fourth, discrimination and complicated procedures in funding legal aid. Fifth, there is no supervision in the application of legal aid.
\end{abstract}

Keywords: Legal Aid; Investigation; Criminal Cases

\begin{abstract}
Abstrak
Perlindungan dan pengakuan hak asasi manusia dari setiap individu atau warga negara merupakan suatu kewajiban bagi negara sebagai konsekuensi logis dari penetapannya sebagai negara hukum dan seseorang berhak untuk diperlakukan sama dihadapan hukum, termasuk bagi rakyat miskin yang sedang bermasalah dengan hukum. Penelitian ini adalah penelitian hukum normatif atau penelitian hukum doktrinal dengan pendekatan inventarisasi hukum, yaitu mengumpulkan norma-norma yang sudah diidentifikasi sebagai norma hukum. Kesimpulan dari penelitian ini adalah Bantuan Hukum bukanlah suatu jaminan dalam tewujudnya access to law and justice bagi rakyat miskin karena penerapan pemberian bantuan hukum dalam tatanan praktik di masyarakat masih menuai beberapa persoalan yang menghambat terwujudnya access to law and justice bagi rakyat miskin. Pertama, kerangka hukum normatif yang tidak bekerja. Kedua, kurangnya kesadaran hukum mengenai bantuan hukum. Ketiga, akses menuju peradilan yang bersifat formalitas. Keempat, diskriminasi dan prosedur yang rumit dalam pendanaan bantuan hukum. Kelima, belum adanya pengawasan dalam penerapan pemberian bantuan hukum.
\end{abstract}

Kata Kunci: Bantuan Hukum; Pemeriksaan; Perkara Pidana

\section{PENDAHULUAN}

\section{A. Latar Belakang}

Perlindungan dan pengakuan hak asasi manusia dari setiap individu 
Muhamad Adystia Sunggara, Yang Meliana, Arifin Faqih Gunawan, Sri Yuliana, Penerapan dan Pemberian Bantuan Hukum Bagi Masyarakat Kurang Mampu, Halaman 138-154

atau warga negara merupakan suatu kewajiban bagi negara sebagai konsekuensi logis dari penetapannya sebagai negara hukum. Indonesia merupakan negara hukum (Pasal 1 ayat (2) Undang-Undang Dasar 1945) yang memiliki kewajiban untuk melakukan perlindungan dan pengakuan akan hak asasi manusia dari setiap individu atau warga negaranya. Penetapan tersebut diikuti dengan pernyataan bahwa setiap warga negara memiliki kedudukan yang sama dihadapan hukum yang dikenal dengan prinsip equality before the law yang termaktub dalam Pasal 27 ayat (1) Undang-Undang Dasar 1945. Konsekuensi dari prinsip equality before the law, seseorang berhak untuk diperlakukan sama dihadapan hukum, termasuk bagi rakyat miskin yang sedang bermasalah dengan hukum. Terlebih lagi, negara Indonesia secara kontitusi pada Pasal 34 ayat (1) Undang-Undang Dasar 1945 menyatakan bahwa fakir miskin dan anak terlantar diperlihara oleh negara. Makna kata "dipelihara" bukan sekedar memberikan kebutuhan akan pangan dan sandang saja, namun juga termasuk kesempatan memperoleh akses hukum dan keadilan (access to law and justice).
Berkaitan dengan hal tersebut, pemerintah mengeluarkan suatu regulasi untuk merealisasikan prinsip dan tujuan tersebut melalui UndangUndang 16 Tahun 2011 tentang Bantuan Hukum (selanjutanya disebut Undang-Undang Bantuan Hukum). Substansi dari undang-undang tersebut mengharuskan para penegak hukum terutama advokat sebagai pemberi bantuan hukum untuk memberikan bantuan hukum secara gratis bagi rakyat miskin di seluruh wilayah Negara Kesatuan Republik Indonesia (NKRI) dan kewajiban tersebut merupakan kewajiban secara normatif bagi advokat sebagai officium nobile sesuai dengan yang tercantum dalam Undang-Undang Nomor 18 tahun 2003 tentang Advokat (selanjutnya disebut Undang-Undang Advokat) untuk memberikan bantuan hukum bagi setiap warga negara saat mereka menghadapi masalah hukum tanpa memandang latar belakang individu, ras, etnis, keyakinan politik, strata sosial, ekonomi dan gender.

Berbicara mengenai prinsip equality before the law, hak asasi manusia, dan access to law and justice bukanlah hal yang mudah untuk diwujudkan, namun pemerintah telah 
Muhamad Adystia Sunggara, Yang Meliana, Arifin Faqih Gunawan, Sri Yuliana, Penerapan dan Pemberian Bantuan Hukum Bagi Masyarakat Kurang Mampu, Halaman 138-154

berupaya untuk merealisasikannya.

Realitas dalam masyarakat mengenai equality before the law, hak asasi manusia dan access to law and justice terkadang realitanya tidak seperti apa yang dibicarakan. Terdapat suatu pertanyaan besar mengenai penyebab penerapan bantuan hukum bagi rakyat miskin belum efektif dan optimal sehingga dari regulasi tersebut belumlah mewujudkan access to law and justice bagi rakyat miskin. Penyebab tersebut merupakan suatu persoalan dalam penerapan bantuan hukum yang harus dicari, diteliti dan diberikan suatu solusi agar penerapan bantuan hukum dapat berjalan optimal dan efektif. Oleh karenanya menjadi suatu hal yang menarik untuk melakukan suatu pengkajian dan penelitian untuk mengetahui persoalanpersoalan dalam penerapan bantuan hukum di Indonesia yang selanjutnya dirumuskan suatu pemikiran agar dapat menjadi solusi untuk mengoptimalkan pemberian bantuan hukum untuk menwujudkan access to law and justice bagi rakyat miskin di Indonesia.

\section{B. Rumusan Masalah}

Berdasarkan latar belakang tersebut, dapat dirumuskan beberapa permasalahan untuk dilakukan pengkajian dan penelitian untuk menjawab permasalahan tersebut. Pertama, Bagaimana persoalan dalam penerapan pemberian bantuan hukum bagi masyarakat kurang mampu ? Kedua, Bagaimana mengoptimalkan pemberian bantuan hukum bagi masyarakat kurang mampu ?

\section{Metode Penelitian}

Penelitian ini adalah penelitian hukum normatif atau penelitian hukum doktrinal dengan pendekatan inventarisasi hukum, yaitu mengumpulkan norma-norma yang sudah diidentifikasi sebagai norma hukum. Sebagai penelitian hukum normatif maka sumber data yang dipergunakan berupa data sekunder, terdiri dari bahan hukum primer, sekunder dan tersier. Analisis data penelitian secara secara kualitatif, yakni membandingkan atau menerapkan peraturan perundangundangan yang berlaku, pendapat para sarjana (doktrin) serta teori-teori hukum lainnya. Kesimpulan penelitian secara deduktif, yakni penarikan kesimpulan diawali dari yang bersifat umum kepada yang bersifat khusus. 
Muhamad Adystia Sunggara, Yang Meliana, Arifin Faqih Gunawan, Sri Yuliana, Penerapan dan Pemberian Bantuan Hukum Bagi Masyarakat Kurang Mampu, Halaman 138-154

PEMBAHASAN

A. Penerapan Pemberian Bantuan Hukum Bagi Masyarakat Kurang Mampu

Peraturan perundang-undangan yang mengatur tentang bantuan hukum diantara lain Undang-Undang Bantuan Hukum, Undang-Undang Advokat, Peraturan Pemerintah Nomor 42 Tahun 2013 tentang Syarat dan Tata Cara Pemberian Bantuan Hukum dan Penyaluran Dana Bantuan Hukum (selanjutnya disebut PP Bantuan Hukum), Peraturan Pemerintah Nomor 83 Tahun 2008 tentang Persyaratan dan Tata Cara Pemberian Bantuan Hukum Secara Cuma-Cuma. Pengaturan tentang bantuan hukum di 2 (dua) undang-undang yang berbeda yaitu Undang-Undang Bantuan Hukum dan Undang-Undang Advokat memberikan asumsi bahwa kedua undang-undang tersebut tumpang tindih. Anggapan adanya benturan antar undang-undang tersebut kemudian menggerakkan beberapa pihak untuk menguji UndangUndang Bantuan Hukum yang kemudian oleh Mahkamah Konstitusi ditolak permohonannya melalui Putusan Mahkamah Konstitusi Nomor 88/PUU-X/2012 atas uji materiil
Undang-Undang Bantuan Hukum terhadap Undang-Undang Dasar 1945.

$$
\text { Undang-Undang Bantuan }
$$

Hukum merupakan sarana negara dalam merepresentatifkan fungsinya sebagai negara hukum, yang mana negara mempunyai wewenang dalam menentukan sarana terhadap aspekaspek penting pemberian bantuan hukum bagi masyarakat miskin atau kelompok masyarakat tertentu. Aspek tersebut yaitu aspek perumusan aturan hukum, aspek pengawasan terhadap mekanisme pemberian bantuan hukum, dan aspek pendidikan masyarakat agar aturan hukum yang sudah dibuat dapat dihayati. ${ }^{1}$

Semangat yang terkandung dalam Undang-Undang Bantuan Hukum jelas berbeda dengan pemberian bantuan hukum yang diatur dalam Undang-Undang Advokat. Pemberian bantuan hukum di UndangUndang Advokat merupakan suatu hal yang bersifat melekat (inherent) bagi profesi yang fungsinya melayani kepentingan publik apalagi advokat yang dikenal sebagai officium nobile.11 Hal tersebut tertuang dalam

\footnotetext{
${ }^{1}$ Dheborah Rhode L, Access to Justice (New York: Oxford University Press, 2004).
} 
Muhamad Adystia Sunggara, Yang Meliana, Arifin Faqih Gunawan, Sri Yuliana, Penerapan dan Pemberian Bantuan Hukum Bagi Masyarakat Kurang Mampu, Halaman 138-154

Putusan Mahkamah Konstitusi Nomor 067/PUU-II/2004.

Negara membentuk aspek penting dalam menjalankan Bantuan Hukum melalui Undang-Undang Bantuan Hukum berhak menentukan siapa yang bisa memberikan bantuan hukum terhadap kelompok masyarakat miskin agar tercapainya access to law and justice salah satunya profesi advokat. Adanya Undang-Undang Bantuan Hukum bukanlah menjadi legal insecurity bagi pelaksanaan Bantuan Hukum, karena UndangUndang Bantuan Hukum merupakan alat dari negara untuk implementasi bantuan hukum, bukan mencapur adukan istilah pemberian bantuan hukum sebagaimana halnya dalam Undang-Undang Advokat. ${ }^{2}$

Selain advokat, yang dapat memberikan bantuan hukum adalah Paralegal, Mahasiswa fakultas hukum, dosen fakultas hukum yang terhimpun dalam suatu badan yang memenuhi persyaratan sebagai pemberi bantuan hukum sebagaimana tercantum pada Pasal 8 Undang-Undang Bantuan Hukum. Hal tersebut menjadi permasalahan juga, karena banyak instansi seperti kepolisian, pengadilan

\footnotetext{
${ }^{2}$ Dheborah Rhode L
}

mempertanyakan legal standing pemberi bantuan hukum selain advokat ketika memegang kuasa untuk menyelesaikan asalah pemohon bantuan hukum. Ditambah lagi Pasal 31 Undang-Undang Advokat mengatakan bahwa setiap orang yang menjalankan tugas profesi layaknya advokat namun bukan advokat dapat dipidana.

Mahkamah

Konstitusi mengeluarkan Putusan Nomor 006/PUU-II-2004 untuk menegaskan bahwa profesi selain Advokat yang memenuhi syarat sebagai pemberi bantuan hukum berhak menerima kuasa untuk menghadap ke instansi tertentu dalam menangani kasus pemohon bantuan hukum dan menyatakan bahwa Pasal 31 UndangUndang Advokat bersifat diskriminatif dan tidak sesuai dengan UndangUndang Dasar 1945. ${ }^{3}$

Undang-Undang Advokat merupakan peraturan yang mengatur syarat-syarat, hak dan kewajiban, menjadi anggota profesi advokat, yang memuat pengawasan terhadap pelaksanaan profesi advokat dalam

${ }^{3}$ MA Sunggara, "Kebijakan Penegakan Hukum Dalam Pemberantasan Narkotika Penyalagunaan Dalam Tahanan Oleh Badan Narkotika Nasional," Jurnal Solusi 18, no. 2 (2020): 139-146 
Muhamad Adystia Sunggara, Yang Meliana, Arifin Faqih Gunawan, Sri Yuliana, Penerapan dan Pemberian Bantuan Hukum Bagi Masyarakat Kurang Mampu, Halaman 138-154

memberikan jasa hukum, baik di dalam maupun di luar pengadilan. Sedangkan Undang-Undang Bantuan Hukum merupakan instrument hukum negara untuk mengimplementasikan konsekuensi logis sebagai negara hukum yaitu adanya access to law and justice. 4 Undang-Undang Bantuan Hukum merupakan peraturan yang mengatur tentang syarat syarat dan teknis bantuan hukum bagi rakyat miskin, serta klasifikasi siapa saja yang dapat menjadi pemberi bantuan hukum. ${ }^{5}$

Access to law and justice merupakan hal yang vital dan mandat terpenting dari United Nations Development Programme untuk mengurangi jumlah kemiskinan dan memperkuat pemerintahan yang demokratis. Access to law and justice bukan sekedar meningkatkan akses ke pengadilan dan menjamin representasi hukum seseorang. Akses terhadap keadilan didefinisikan sebagai kemampuan masyarakat untuk mencari dan memperoleh obat melalui lembaga formal atau informal keadilan bagi

${ }^{4}$ Tata Wijayanta, "Bantuan Huku Golongan Tidak Mampu,” Jurnal Yuridika 7, no.2 (2012). 5 Mosgan Situmorang, Tanggung Jawab Negara dan Advokat dalam Memberikan Bantuan Hukum (Jakarta: BPHN kementerian Hukum dan HAM, 2011). keluhan sesuai dengan standar hak asasi manusia.

Hal ini merupakan akses bagi masyarakat, khususnya kelompok miskin terhadap mekanisme yang adil, efektif dan akuntabel untuk melindungi hak, menghindari penyalahgunaan adalah kemampuan masyarakat untuk memperoleh dan mendapatkan penyelesaian melalui mekanisme formal dan informal dalam sistem hukum, serta kemampuan untuk memperoleh dan terlibat dalam proses pembuatan dan penerapan dan pelembagaan hukum.

Akses terhadap keadilan dalam konteks Indonesia mengacu pada keadaan dan proses di mana negara menjamin terpenuhinya hak-hak dasar berdasarkan UUD 1945 dan prinsipprinsip universal hak asasi manusia, dan menjamin akses bagi setiap warga negara (claim holder) agar dapat memiliki kemampuan untuk mengetahui, memahami, menyadari dan menggunakan hak-hak dasar tersebut melalui lembaga-lembaga formal maupun informal, didukung oleh keberadaan mekanisme keluhan publik (public complaint mechanism) yang mudah diakses masyarakat dan responsif, agar dapat memperoleh 
Muhamad Adystia Sunggara, Yang Meliana, Arifin Faqih Gunawan, Sri Yuliana, Penerapan dan Pemberian Bantuan Hukum Bagi Masyarakat Kurang Mampu, Halaman 138-154

manfaat yang optimal untuk memperbaiki kualitas kehidupannya sendiri. ${ }^{6}$

Usaha pemerintah mencapai access to law and justice salah satunya dengan mengeluarkan kebijakan affirmative action. Affirmative action ini merupakan merupakan cara yang banyak dipilih oleh negara sebagai jawaban terhadap kondisi sosial yang diskriminatif, adanya ketidaksetaraan dan marginalisasi di segala bidang kehidupan akibat struktur patriarki di level publik dan privat.

Elizabeth S. Anderson, mendefiniskan affirmative action secara luas termasuk semua kebijakan yang mempunyai tujuan. Pertama, mengupayakan penghilangan hambatan dalam sistem dan norma terhadap kelompok sebagai akibat sejarah ketidakadilan dan ketidaksetaraan, dan/ atau, Kedua, mengupayakan promosi masyarakat yang inklusif sebagai prasyarat demokrasi, integrasi, dan pluralisme; Ketiga, mengupayakan kesetaraan atas dasar pengklasifikasian identitas (ras, gender, etnisitas, orientasi seksual, dsb). Salah satu

6 Suradji, Etika dan Penegakan Kode Etik Profesi Hukum (Advokat) (Jakarta: Badan Pembinaan Hukum Nasional Departemen Hukum dan HAM RI, 2008). sarana terpenting untuk menerapkan affirmative action adalah hukum dan jaminan pelaksanaannya harus ada konstitusi dan undang-undang.

Menurut Frans Hendra Winarta menyatakan bahwa, bantuan hukum merupakan jasa hukum yang khusus diberikan kepada fakir miskin yang memerlukan pembelaan secara cumacuma, baik di luar maupun di dalam pengadilan, secara pidana, perdata dan tata usaha negara, dari seseorang yang mengerti seluk beluk pembelaan hukum, asas-asas dan kaidah hukum, serta hak asasi manusia. Pengertian lain, menurut Adnan Buyung Nasution, bantuan hukum adalah khusus bantuan hukum bagi golongan masyarakat yang berpenghasilan rendah atau dalam bahasa populer miskin, ukuran kemiskinan sampai saat ini masih tetap merupakan masalah yang sulit dipecahkan, bukan saja bagi negaranegara berkembang bahkan negaranegara yang sudah majupun masih tetap menjadi masalah.

Bantuan Hukum memiliki 4 (empat) konsep dalam penerapannya. Pertama, Konsep Bantuan Hukum Tradisional, adalah pelayanan hukum yang diberikan kepada masyarakat miskin secara individual, sifat dari bantuan 
Muhamad Adystia Sunggara, Yang Meliana, Arifin Faqih Gunawan, Sri Yuliana, Penerapan dan Pemberian Bantuan Hukum Bagi Masyarakat Kurang Mampu, Halaman 138-154

hukum pasif dan cara pendekatannya sangat formal-legal. Kedua, Konsep Bantuan Hukum Konstitusional, adalah bantuan hukum untuk rakyat miskin yang dilakukan dalam rangka usahausaha dan tujuan yang lebih luas seperti: menyadarkan hak-hak masyarakat miskin sebagai subjek hukum, penegakan dan pengembangan nilai-nilai hak asasi manusia sebagai sendi utama bagi tegaknya negara hukum. Ketiga, Konsep Bantuan Hukum Struktural, adalah kegiatan yang bertujuan menciptakan kondisikondisi bagi terwujudnya hukum yang mampu mengubah struktur yang timpang menuju kearah struktural yang lebih adil, tempat peraturan hukum dan pelaksanaannya dapat menjamin persamaan kedudukan baik dilapangan hukum atau politik. Konsep bantuan hukum struktural ini erat kaitannya dengan kemiskinan structural. Keempat, bantuan hukum responsif diberikan kepada fakir miskin secara cuma-cuma dan meliputi semua bidang hukum dan hak asasi manusia serta tanpa membedakan pembelaan baik perkara individual maupun kolektif. Jasa yang diberikan dalam bantuan hukum responsif berupa penyuluhan hukum tentang hak asasi manusia dan proses hukum hak untuk dibela oleh organisasi bantuan hukum dan atau advokat, pembelaan dalam mengatasi masalah masalah hukum yang kongkrit, pembelaan yang berkualitas didalam pengadilan agar menghasilkan yurisprudensi yang lebih tegas tepat jelas dan benar, pembaharuan hukum melalui keputusan pengadilan yang berpihak kepada kebenaran dan pembentukan undang-undang yang sesuai dengan sistem nilai dan budaya yang ada dalam masyarakat untuk menyukseskan konsep tersebut bantuan hukum harus menjadi gerakan nasional yang didukung oleh negara dan masyarakat. $^{7}$

Konsep bantuan hukum yang dapat membantu terwujudnya access to law and justice bagi rakyat miskin adalah konsep bantuan hukum secara responsive dan struktrural. Apabila konsep pemberian bantuan hukum tersebut di kombinasikan dengan konsep access to law and justice maka bukanlah suatu hal yang mustahil bagi rakyat miskin untuk mengakses hukum dan mendapatkan keadilan. ${ }^{8}$

\footnotetext{
7 The Indonesia Legal Resource, Kajian Awal Hasil Verifikasi dan Akreditasi Organisasi Bantuan Hukum (Jakarta: The Indonesia Legal Resource, 2013).

${ }^{8}$ The Indonesia Legal Resource
} 
Muhamad Adystia Sunggara, Yang Meliana, Arifin Faqih Gunawan, Sri Yuliana, Penerapan dan Pemberian Bantuan Hukum Bagi Masyarakat Kurang Mampu, Halaman 138-154

B. Pengoptimalan Pemberian terakhir menerima sepenuhnya Bantuan Hukum Bagi melakukan pemberian bantuan hukum.

\section{Masyarakat Kurang Mampu}

Perwujudan dari pemberian bantuan hukum di masyarakat terdapat permasalahan pada penerapannya sehingga akibatnya tidak terwujudnya access to law and justice bagi rakyat miskin, adapun permasalahan tersebut adalah :

\section{Kerangka Hukum Normatif} Pemberian Bantuan Hukum yang Belum Berjalan Secara Utuh

Mengutip dari pendapat Satjipto Rahardjo "Hukum yang diciptakan dan tidak pernah dijalankan pada hakikatnya telah berhenti menjadi hukum". Kerangka hukum normatif mengenai pemberian bantuan hukum dalam tataran praktik di masyarakat, terutama pada konstituen regulasi tersebut yaitu rakyat miskin masih belum dijalankan secara optimal oleh para advokat sebagai salah satu pemberi bantuan hukum. Terdapat tiga hal perilaku advokat dalam menghadapi persoalan bantuan bagi rakyat miskin yaitu mengindari dengan berbagai alasan, menerima perkara dengan syarat perkara tersebut harus menarik media massa sehingga menaikan pamor advokat, dan yang
Para sebagian advokat lebih cenderung menyukai membela para klien mengenai keatas ketimbang rakyat miskin, hal ini bisa mereduksi profesi advokat sebagai profesi mulia menjadi profesi komersil. Berdasarkan hasil penelitian terdapat hampir sebagian advokat enggan untuk memberikan bantuan hukum/pembelaan secara pro bono publico kepada rakyat miskin dengan penolakan perkara secara tidak obyektif. Hal obyektif yang dimaksud disini adalah penolakan terhadap perkara yang bukan menjadi masalah hukum, artinya masalah tersebut tidak termasuk kategori masalah hukum yang tidak mengakibatkan akibat hukum. Penolakan secara tidak obyektif advokat berdasarkan hasil penelitian seperti menolak perkara pelecehan seksual, melawan pemerintah, atau sampai kepada menolak perkara karena perkara tersebut tidaklah perkara besar yang tidak akan dimuat oleh media massa. Penolakan perkara yang dialami rakyat miskin secara tidak obyektif oleh advokat adalah sebuah penyimpangan terhadap kerangka hukum normative dari pemberian bantuan hukum, karena 
Muhamad Adystia Sunggara, Yang Meliana, Arifin Faqih Gunawan, Sri Yuliana, Penerapan dan Pemberian Bantuan Hukum Bagi Masyarakat Kurang Mampu, Halaman 138-154

secara normatif bantuan hukum diberikan tanpa mengenal masalah hukum apa yang akan ditangani dan siapa yang dibela, melainkan bagaimana rakyat miskin mendapatkan hak untuk access to law and justice ketika rakyat miskin bermasalah dengan hukum. Ketika kerangka normatif pemberian bantuan hukum tidak di jalankan oleh advokat maka hukum mengenai bantuan hukum tersebut tidaklah menjadi hukum dengan kata lain regulasi mengenai bantuan hukum hanyalah mitos yang dibuat oleh negara.

\section{Kurangnya Kesadaran Hukum}

Rakyat Miskin

Seseorang akan melanggar
hukum terkadang disebabkan
ketidakfahamannya akan hukum,
bahkan dapat juga orang tersebut akan
dibodohi oleh oknum untuk mengambil

keuntungan. Mengutip dari pendapatnya John Rawls "semua sistem hukum akan gagal bila tidak disemangati oleh suatu sikap moral pribadi yang sejati (justice as farness) di masyarakat." Berdasarkan pendapat tersebut jika dibenturkan dengan penerapan bantuan hukum bagi rakyat miskin, apabila rakyat miskin dalam tataran praktiknya masih kurang kesadaran hukum dan pengetahuan hukum akan pentingnya bantuan hukum, maka pemberian bantuan hukum tersebut akan tidak berfungsi secara maksimal. Perspektif penerapan pemberian bantuan hukum bagi rakyat miskin, tidak hanya dilihat sebatas memenuhi kebutuhan masyarakat akan pendampingan dalam setiap proses hukum, tetapi lebih dari itu, yaitu menjadikan masyarakat mengerti hukum dan dapat mengkritisi produk hukum yang ada, yaitu dengan memberikan pendidikan hukum dan kewarganegaraan bagi masyarakat (civic education). Perspektif tersebut secara ideal dapat menyelesaikan suatu persoalan ini, akan tetapi hal itu belum sesuai dalam tataran implementasinya. Berdasarkan hasil penelitian yang dilakukan, ditemukan beberapa advokat dan lembaga bantuan hukum yang masih cenderung memandang pemberian bantuan hukum bersifat pasif Perspektif pemberian bantuan hukum bersifat pasif dapat menjadi suatu parasit yang dapat mereduksi optimalisasi pemberian bantuan hukum. Perspektif disini dapat diilustrasikan seperti, pemberian bantuan hukum yang diberikan oleh advokat/LBH atas tunjukan dari Aparat kepolisian atau 
Muhamad Adystia Sunggara, Yang Meliana, Arifin Faqih Gunawan, Sri Yuliana, Penerapan dan Pemberian Bantuan Hukum Bagi Masyarakat Kurang Mampu, Halaman 138-154

pengadilan sebagai penasehat hukum karena adanya penyediaan dana dari pengadilan tersebut dan perkara yang hukumannya di atas 15 (lima belas) tahun penjara sesuai anjuran KUHAP.

Berdasarkan Perma Nomor 1

Tahun 2014 tentang Pedoman Pemberian Layanan Hukum Bagi Masyarakat Tidak Mampu di Pengadilan, lembaga pengadilan menyediakan suatu anggaran untuk memberian bantuan hukum secara cuma-cuma dan membentuk Pos Bantuan Hukum (Posbakum). Akses bantuan hukum yang diberikan oleh pengadilan dengan menunjuk advokat atau Lembaga Bantuan Hukum (LBH) yang didanai oleh pengadilan, hal ini yang disebut dengan kerjasama kelembagaan (Pasal 26 Perma No. 1 Tahun 2014) sedangkan Posbakum sendiri berfungsi untuk memberikan layanan konsultasi hukum, pembuatan dokumen hukum yang dibutuhkan dan informasi mengenai advokat/LBH yang menerima bantuan hukum (Pasal 25 Perma Nomor 1 Tahun 2014). Hadirnya akses bantuan hukum bukan tanpa masalah, masalah yang muncul adalah 'keterbatasan anggaran yang disediakan' sehingga apabila anggaran yang ditetapkan sudah diserap semuanya lalu ada perkara rakyat miskin yang memerlukan bantuan hukum secara cuma-cuma atau perkara tersebut perlu naik pada pengadilan tingkat banding, kasasi atau peninjauan kembali dapat diabaikan begitu saja, karena anggaran yang disediakan sudah habis terserap semuanya. Hal inilah yang akan memunculkan persoalan selanjutnya.

Berdasarkan perspektif yang memandang pemberian bantuan hukum bersifat pasif dan keterbatasan akses yang diberikan oleh pengadilan akan mereduksi optimalisasi pemberian bantuan hukum bagi rakyat miskin. Hal inilah menjadikan urgensi kepekaan advokat/LBH untuk memandang pemberian bantuan hukum secara aktif dan tidak terlalu mengandalkan akses yang diberikan oleh pengadilan.

\section{Akses Menuju Peradilan Hanya}

\section{Bersifat Formalitas}

Berawal dari kalimat sarkas yaitu "mata pedang hukum lebih tajam kebawah daripada keatas" yang artinya rasa keadilan dari hukum tidak menyentuh bagi kelas bawah, sedangkan mereka yang memiliki kelas sosial lebih tinggi maka akan dengan mudah mendapatkan perlakuan yang lebih istimewa. Kesalahan pada 
Muhamad Adystia Sunggara, Yang Meliana, Arifin Faqih Gunawan, Sri Yuliana, Penerapan dan Pemberian Bantuan Hukum Bagi Masyarakat Kurang Mampu, Halaman 138-154

penerapan hukum maupun subyek hukum (error in persona) yang dilakukan oleh hakim sebagai pengendali proses pengadilan bukanlah hal yang langka pada praktik peradilan di Indonesia, hal inilah yang disebut dengan peradilan sesat. Seringkali dalam praktik di masyarakat, terutama rakyat miskin mengalami/menjadi korban dari peradilan sesat, walaupun terdapat suatu akses banding, kasasi maupun peninjauan kembali untuk menghindari peradilan sesat, akan tetapi akses tersebut belum mungkin digunakan bagi rakyat miskin karena akan mengeluarkan banyak biaya yang tidak mampu untuk dibayarkan.

Berdasarkan hal tersebut adanya Undang-Undang Bantuan Hukum bukanlah suatu jaminan bagi rakyat miskin untuk mendapatkan akses banding, kasasi maupun peninjauan kembali. Hal ini dikarenakan pada tataran praktik di masyarakat penerapan bantuan hukum diberikan hanya bersifat formalitas oleh sebagian advokat maupun LBH. ${ }^{9}$ Berdasarkan hasil penelitian yang dilakukan, sebagian pemberian bantuan

9 Siti Nuraisyah, Dewi, "Bantuan Hukum Untuk Orang Miskin," Jurnal Justicia 8, no.2 (2013). hukum dilakukan sampai kepada peradilan tingkat pertama saja. Dari sudut pandang advokat/LBH, hal itu dilakukan atas dasar permintaan klien (rakyat miskin), akan tetapi dari sudut pandang rakyat miskin permintaan (tidak mengajukan banding, kasasi, peninjauan kembali) atas dasar kepasrahan dan tidak memiliki biaya untuk mengakses hal tersebut. hukum murni gratis, tanpa ada biaya-biaya lain, akan tetapi hal itu tidak konsisten dalam dunia praktiknya di masyarakat, dimana rakyat miskin tetap dipungut biaya seperti biaya fotocopy, pemanggilan saksi dan ahli, maupun biaya transport pun menjadi tanggungan rakyat miskin dalam menerima bantuan hukum. Pemungutan biaya tersebut dilakukan atas dasar untuk menghidupi bekerjanya advokat atau LBH. Padahal memungut biaya dalam bantuan hukum itu merupakan suatu larangan dengan hukuman penjara paling lama 1 tahun dan denda lima puluh juta rupiah (Pasal 20 jo Pasal 21 Undang-Undang Tentang Bantuan Hukum). Hal ini menjadi suatu dilema dalam penerapan bantuan hukum bagi rakyat miskin.

Suatu hal yang menjadi dilema, dimana Undang-Undang Bantuan 
Muhamad Adystia Sunggara, Yang Meliana, Arifin Faqih Gunawan, Sri Yuliana, Penerapan dan Pemberian Bantuan Hukum Bagi Masyarakat Kurang Mampu, Halaman 138-154

Hukum mengharuskan memberikan bantuan hukum bagi rakyat miskin secara cuma-cuma yang bersumber dari Anggaran Pendapatan dan Belanja Negara (APBN) maupun Anggaran Pendapatan dan Belanja Daerah (APBD) dan Perma Nomor 1 Tahun 2014 yang bersumber dari anggaran pengadilan setempat.

\section{Diskriminasi dan Prosedur yang} Rumit dalam Pendanaan Bantuan Hukum

Berbicara mengenai pendanaan atau uang merupakan suatu hal yang menarik, karena dengan hal itu segala aktivitas pekerjaan akan mudah dan karena hal itu pula dapat merubah suatu ideologi. Pendanaan dalam bantuan hukum merupakan salah satu bentuk tanggung jawab dan semangat yang diberikan kepada negara kepada para advokat/LBH karena mewajibkan untuk memberikan bantuan hukum kepada rakyat miskin. Undang-Undang Bantuan Hukum memberikan pendanaan bagi advokat/LBH dengan berbagai macam syarat dan prosedur yang rumit. Syarat yang diberikan lebih cenderung kepada dapat terpenuhi oleh LBH saja, itupun harus ada proses seleksi yang biasa disebut dengan akreditasi sebagai legitimasi untuk menyerap pendanaan bantuan hukum tersebut, hal ini bertendensi adanya suatu diskriminasi.

\section{Belum Adanya Pengawasan dalam} Penerapan Bantuan Hukum

Pengawasan adalah suatu hal yang terpenting untuk menjaga agar tidak kelewat batas ataupun menyalahgunakan. Kelalaian bagi pembuat undang-undang terutama Undang-Undang Bantuan Hukum secara normatif tidak mengakomodir ketentuan Pengawasan dalam penerapan bantuan hukum.Pengawasan dalam penerapan bantuan hukum sangatlah berperan penting untuk menjaga keseimbangan relasi bantuan hukum tetap berjalan sesuai peruntukannya. Pengawasan yang longgar, dapat membuka celah untuk menyelewengkan uang negara (korupsi) atau sampai kepada mengorbankan harapan untuk terwujudnya access to law and justice bagi rakyat miskin.

Perlu diketahui sebelumnya bahwa penerapan pemberian bantuan hukum dalam praktik di masyarakat kurang optimal dikarenakan masih memiliki berbagai macam persoalan yang bersifat sistematis sehingga berdampak pada belum terwujudnya access to law and justice bagi rakyat 
Muhamad Adystia Sunggara, Yang Meliana, Arifin Faqih Gunawan, Sri Yuliana, Penerapan dan Pemberian Bantuan Hukum Bagi Masyarakat Kurang Mampu, Halaman 138-154

miskin. Oleh karenanya dibutuhkan suatu gagasan yang dapat menyelesaikan persoalan dalam penerapan pemberian bantuan hukum bagi rakyat miskin, sehingga terwujudnya access to law and justice bukanlah sekedar mitos atau janji manis yang dibuat oleh negara. Mengacu pada definisi dan strategi terwujudnya access to law and justice, terdapat beberapa upaya dalam mengoptimal penerapan pemberian bantuan hukum bagi rakyat miskin sebagai berikut:

\section{a. Stimulan}

Advokat/LBH

Memberikan Bantuan Hukum

Menurut Organisasi Advokat SeDunia yaitu BAR Association, stimulan adalah salah satu cara membuat advokat untuk mau secara sadar memberikan bantuan hukum, karena cara yang bersifat represif tidaklah efektif untuk menyadarkan advokat memberikan bantuan hukum. Cara yang bersifat stimulan ini dilakukan seperti mengadakan suatu penghargaan agar menginspirasi advokat lain memberikan bantuan hukum kepada rakyat miskin. Berdasarkan hal tersebut cara ini sebagai suatu alternatif cara untuk menyelesaikan persoalan pertama.

b. Bantuan Hukum yang Bersifat Aktif, Responsif dan Struktural
Urgensi dalam merubah orientasi bantuan hukum agar bersifat aktif, responsif dan struktural diperlukan karena suatu keterbatasan dari klien (rakyat miskin) yang belum mempunyai pengetahuan dan kesadaran hukum dan anggaran yang disediakan pengadilan maupun negara. Bersifat aktif-responsif artinya advokat harus lebih mengetahui kebutuhan klien (rakyat miskin) ketika bermasalah hukum tanpa harus menunggu permintaan klien, aparat penegak hukum, maupun pengadilan. Bersifat struktural disini artinya advokat dalam memberikan bantuan hukum tidak hanya untuk menyelesaikan masalah di dalam pengadilan saja (penasihat hukum), akan tetapi advokat/LBH lebih membuat klien nya mengerti akan hukum sehingga terciptalah suatu kesadaran hukum secara struktural, hal ini menempatkan advokat selain sebagai penasihat hukum juga sebagai mentor hukum.

\section{c. Terjamahnya Seluruh Akses Menuju Peradilan}

Ketika para advokat/LBH sudah menyepakati orientasi bantuan hukum itu harus bersifat aktif, responsif dan struktrual maka akan menjadi suatu niscaya terjamahnya seluruh akses menuju peradilan (seperti pengadilan tingkat pertama, banding, kasasi, maupun peninjauan kembali), artinya klien dapat menggunakan haknya secara penuh untuk mengakses hukum dan keadilan. 
Muhamad Adystia Sunggara, Yang Meliana, Arifin Faqih Gunawan, Sri Yuliana, Penerapan dan Pemberian Bantuan Hukum Bagi Masyarakat Kurang Mampu, Halaman 138-154

\section{d. Memurnikan Makna Gratis dalam Pemberian Bantuan Hukum}

Pemberian bantuan hukum secara gratis bukan suatu hal yang mustahil terwujud, ketika suatu kebijakan dan mekanisme prosedur dapat dirubah agar lebih mudah penyerapan dana bantuan hukum, baik berasal dari APBN, APBD maupun pengadilan (Mahkamah Agung). Perubahan tersebut dapat dimulai dari prosedur akreditasi dan mekanisme penyerapan dana bantuan hukum agar dipermudah tanpa mengurangi kualitas, sehingga dapat diakses oleh setiap advokat/LBH maupun organisasi advokat. Kemudahan yang diberikan dapat berupa dibuatnya suatu kantor cabang/lembaga yang mengurusi penyerapan dana bantuan hukum di setiap kota/kabupaten karena selama ini penyerapan dana harus diurus di kantor wilayah yang berada di provinsi, selain itu sambil menunggu dibentuknya cabang di setiap kota/ kabupaten dapat dikombinasikan dengan memaksimalkan secara online, baik melalui sistemnya maupun pelatihan sumber daya manusianya. Ketika prosedur akreditasi dan mekanisme penyerapan dana bantuan hukum sudah dipermudah, maka bukanlah suatu hal yang mustahil, terwujudnya makna gratis dalam pemberian bantuan hukum bagi rakyat miskin. Artinya para advokat/LBH tidak akan ragu dalam memberikan bantuan hukum secara cuma-cuma, karena dari penyerapan dana dapat membantu menghidupkan aktivitas pekerjaannya

e. Pengawasan dalam Penerapan Pemberian Bantuan Hukum

Berawal dari belum adanya pengawasan dalam penerapan bantuan hukum baik secara normatif maupun implementasi di masyarakat, maka diperlukannya suatu sistem pengawasan untuk mengawasi beberapa komponen dari penerapan bantuan hukum tersebut. Pengawasan tersebut meliputi, dijalankan atau tidaknya pemberian bantuan hukum, digunakan atau tidaknya akses menuju peradilan, kinerja advokat atau LBH dalam memberikan bantuan hukum, dalam hal ini tentunya diperlukan pendapat dari masyarakat maupun klien yang pernah menjadi penerima bantuan hukum, dan pengawasan yang terakhir mengenai penyerapan dana yang melihat sesuai atau tidaknya dana yang digunakan untuk kepentingan bantuan hukum, agar tidak terjadinya penggelapan atau korupsi dana bantuan hukum. Setelah materi dalam pengawasan sudah diketahui maka yang tidak kalah penting adalah pengawasnya, yang dapat terdiri dari pemerintah, organisasi advokat dan masyarakat. Berdasarkan hal tersebut, apabila gagasan mengenai 5 (lima) upaya dalam mengoptimalkan pemberian bantuan hukum bagi rakyat miskin telah diterima dan dilakukan, maka bukanlah suatu hal yang mustahil 
Muhamad Adystia Sunggara, Yang Meliana, Arifin Faqih Gunawan, Sri Yuliana, Penerapan dan Pemberian Bantuan Hukum Bagi Masyarakat Kurang Mampu, Halaman 138-154

akan terwujudnya access to law and justice bagi rakyat miskin. ${ }^{10}$

\section{KESIMPULAN}

Adanya Undang-Undang
Bantuan Hukum bukanlah suatu
jaminan dalam tewujudnya access to
law and justice bagi rakyat miskin
karena penerapan pemberian bantuan hukum dalam tataran praktik dimasyarakat masih menuai beberapa persoalan yang menghambat terwujudnya access to law and justice bagi rakyat miskin. Pertama, kerangka hukum normatif yang tidak bekerja. Kedua, kurangnya kesadaran hukum mengenai bantuan hukum. Ketiga, akses menuju peradilan yang bersifat formalitas. Keempat, diskriminasi dan prosedur yang rumit dalam pendanaan bantuan hukum. Kelima, belum adanya pengawasan dalam penerapan pemberian bantuan hukum. Persoalanpersoalan tersebut menjadikan penerapan bantuan hukum bagi rakyat miskin kurang optimal.

Berdasarkan beberapa persoalan yang dihadapi dalam penerapan pemberian bantuan hukum,

10 YLBHI, Panduan Bantuan Hukum di Indonesia (Jakarta: Yayasan Obor Indonesia, 2014). terdapat beberapa gagasan berupa suatu upaya yang dapat mengoptimalkan penerapannya. Pertama, stimulan untuk advokat/LBH dalam memberikan bantuan hukum. Kedua, bantuan hukum yang bersifat aktif, responsif dan struktural. Ketiga, terjamahnya seluruh akses dalam peradilan. Keempat, memurnikan makna gratis dalam pemberian bantuan hukum Kelima, Pengawasan dalam penerapan pemberian bantuan hukum. Upayaupaya tersebut merupakan suatu gagasan yang dapat mengoptimalkan pemberian bantuan hukum, sehingga bukan suatu hal yang mustahil untuk terwujudnya access to law and justice bagi rakyat miskin. Seyogyanya pemerintah merevisi peraturan perundang-undangan mengenai bantuan hukum terkait prosedur akreditasi dan pendanaan serta menambahkan pengawasan dalam penerapannya. Seyogyanya advokat dan LBH maupun OBH mementingkan kepentingan klien daripada kepentingan pribadi yang berorientasi pada moral bukan pada keuntungan ekonomi semata. Ketiga, seyogyanya masyarakat dapat memahami pentingnya bantuan hukum sehingga memiliki kesadaran hukum sehingga 
Muhamad Adystia Sunggara, Yang Meliana, Arifin Faqih Gunawan, Sri Yuliana, Penerapan dan Pemberian Bantuan Hukum Bagi Masyarakat Kurang Mampu, Halaman 138-154

dapat bersama-sama (negara dan advokat/LBH) mewujudkan access to law and justice.

\section{DAFTAR PUSTAKA}

Dheborah Rhode L. Access to Justice.

New York: Oxford University

Press, 2004.

Siti Nuraisyah, Dewi. "Bantuan Hukum Untuk Orang Miskin," Jurnal Justicia 8, no.2 (2013).

Situmorang, Mosgan. Tanggung Jawab

Negara dan Advokat dalam

Memberikan Bantuan Hukum.

Jakarta: BPHN kementerian

Hukum dan HAM, 2011.

Sunggara, MA. "Kebijakan Penegakan

Hukum Dalam Pemberantasan

Narkotika Penyalagunaan Dalam

Tahanan Oleh Badan Narkotika

Nasional," Jurnal Solusi 18, no.

2 (2020): 139-146.

Suradji. Etika dan Penegakan Kode

Etik Profesi Hukum (Advokat).

Jakarta: Badan Pembinaan

Hukum Nasional Departemen

Hukum dan HAM RI, 2008.

The Indonesia Legal Resource. Kajian

Awal Hasil Verifikasi dan

Akreditasi Organisasi Bantuan

Hukum (Jakarta: The Indonesia

Legal Resource, 2013).

Wijayanta, Tata. "Bantuan Huku

Golongan Tidak Mampu," Jurnal

Yuridika 7, no.2 (2012).

YLBHI. Panduan Bantuan Hukum di Indonesia. Jakarta: Yayasan Obor Indonesia, 2014. 